\title{
Two-day treatment with metronidazole in vaginal trichomoniasis
}

\author{
K: R. WOODCOCK \\ Department of Venereology, St. Mary's Hospital, Paddington, London
}

Recent studies have demonstrated that the traditional 7 -day course of metronidazole at a dosage of $200 \mathrm{mg}$. three times a day is not the only schedule effective in trichomoniasis (McClean, 1971; Csonka, 1971; Woodcock, 1972). It was decided to assess the efficacy of metronidazole $400 \mathrm{mg}$. four times a day for 2 days; this dosage would facilitate its administration with tetracycline $500 \mathrm{mg}$. four times a day, a schedule sometimes used as an alternative to penicillin in the treatment of gonorrhoea.

\section{Methods}

The patients taking part in the trial were attending the St. Mary's Hospital Special Clinic, and were diagnosed by routine darkfield microscopy of the vaginal secretion as having vaginal trichomoniasis. When cervical cytology was investigated this often confirmed the diagnosis, but it was not used as a diagnostic criterion nor as a test of cure. Cultural methods were not used because previous experience of their use in this clinic had shown them to be not substantially more reliable than simple microscopy; nor was any attempt made to diagnose trichomoniasis in the male consorts, many of whom were routinely

Received for publication April 14, 1972 treated with metronidazole $200 \mathrm{mg}$. three times a day for 1 week.

Patients were included in the trial whenever the diagnosis was made while the doctor conducting the trial was on duty. The only patients excluded were those who had already been treated for a trichomonal infection in the previous 3 months. The patients were asked to return in 1 week and again after 1 month for repeat tests; further visits were made at the discretion of the patient, but an interval of at least 3 months elapsed before the results for each patient were reviewed.

The criteria for diagnosis and assessment of cure, although satisfactory for routine clinical work, might be judged inadequate for a scientific study. It was therefore decided to establish a control group of patients by the same criteria, and to treat them with the standard course of metronidazole $200 \mathrm{mg}$. three times a day for 7 days. The use of a control group made the difficult task of distinguishing between treatment failure and re-infection of less importance, as the results were to be judged relatively rather than in terms of absolute success or failure. The controls were patients in whom the diagnosis was made when the doctor conducting the trial was not on duty.

\section{Material}

The preliminary data are shown in Tables I and II.

TABLE I Concurrent diagnoses in control and trial groups

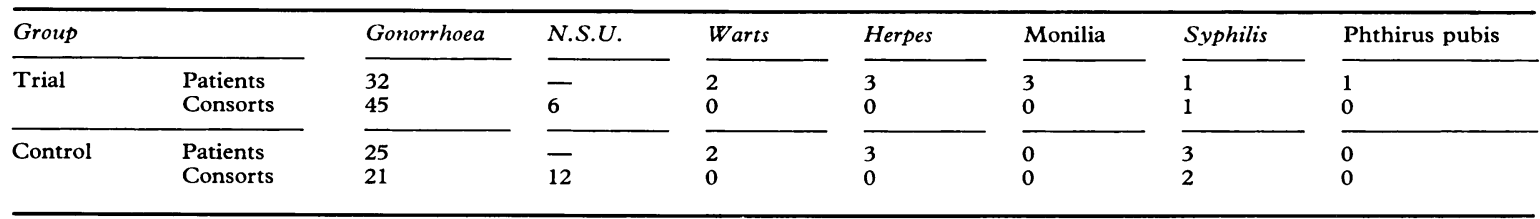

TABLE I I Marital status and oral contraceptive use in control and trial groups

\begin{tabular}{|c|c|c|c|c|}
\hline Group & Marital status & On 'pill' & Not on 'pill' & Total \\
\hline
\end{tabular}


TRIAL GROUP (114 patients)

The average age was 23.9 years; 20 per cent. were married, and 28.9 per cent. were taking the contraceptive pill; 32 of the patients and $\mathbf{4 5}$ of their consorts were diagnosed as having gonorrhoea, six of the consorts had non-specific urethritis, and a total of eleven other diagnoses was made.

\section{CONTROL GROUP (102 patients)}

The average age was $25 \cdot 3$ years, $19 \cdot 7$ per cent. were married and 36.4 per cent. were taking oral contraceptives; 25 of the patients and 21 of their consorts were diagnosed as having gonorrhoea, twelve of the consorts had nonspecific urethritis, and a total of ten other diagnoses was made.

Table III shows the results obtained by cytological examination in both groups of patients and in those with and without gonorrhoea. There was no evidence of malignancy in any patient and no significant difference in the reporting of Trichomonas vaginalis from cytology in the different sub-groups.

\section{Results}

These are shown in Table IV.

In the trial group, 75 returned for follow-up tests; after 4 weeks there had been eight recurrences (10.7 per cent. of those followed) and a further nine recurrences were revealed by later visits, bringing the total to seventeen $(22 \cdot 7$ per cent. of those followed).

In the control group, 68 returned for follow-up tests; after 4 weeks there had been five recurrences (7.3 per cent. of those followed), and later visits revealed a further eight, bringing the total to thirteen $(19 \cdot 1$ per cent. of those followed).

\section{SERUM LEVELS OF METRONIDAZOLE}

Fig. 1 shows the serum levels from four volunteers 3 and 24 hours after the first dose, and 12 hours after the final dose. Serum levels from eight subjects who had a single blood sample taken 36 hours after

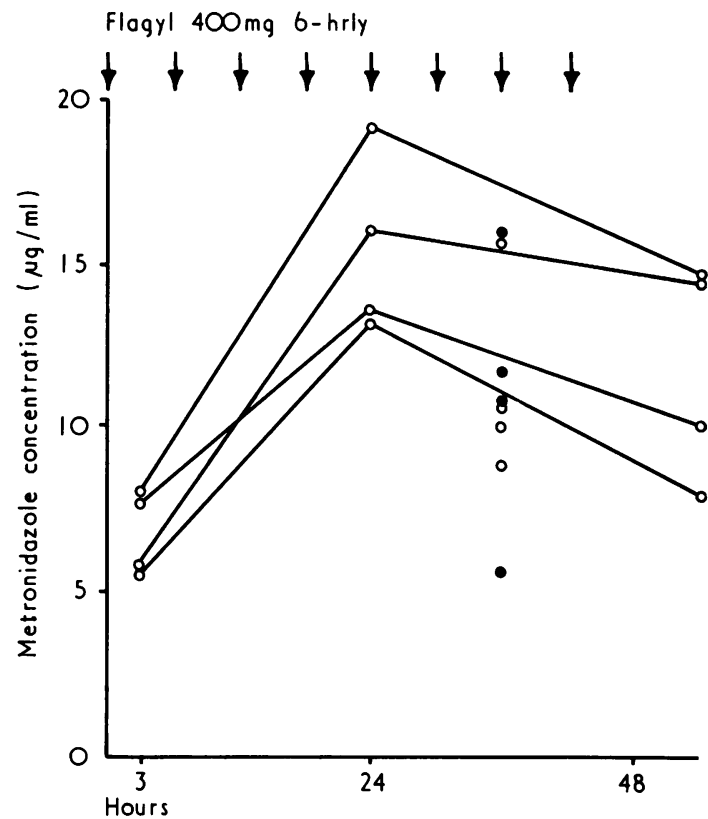

FIG. 1 Serum levels of metronidazole in subjects on metronidazole alone $(O)$ and on metronidazole and tetracycline (๑)

TABLE II I T. vaginalis in cervical cytology in control and trial groups of patients with trichomoniasis and with and without gonorrhoea

\begin{tabular}{|c|c|c|c|c|}
\hline \multirow{2}{*}{ Group } & \multirow{2}{*}{ Gonococci } & \multicolumn{3}{|c|}{ Cervical cytology ( $T$. vaginalis) } \\
\hline & & Positive & Negative & Not tested \\
\hline Trial & $\begin{array}{l}\text { Found } \\
\text { Not found }\end{array}$ & $\begin{array}{l}18 \\
53\end{array}$ & $\begin{array}{r}3 \\
18\end{array}$ & $\begin{array}{l}11 \\
11\end{array}$ \\
\hline Control & $\begin{array}{l}\text { Found } \\
\text { Not found }\end{array}$ & $\begin{array}{l}12 \\
40\end{array}$ & $\begin{array}{r}5 \\
18\end{array}$ & $\begin{array}{r}8 \\
19\end{array}$ \\
\hline
\end{tabular}

TABLE IV Follow-up and results in control and trial groups

\begin{tabular}{|c|c|c|c|c|c|c|c|c|}
\hline \multicolumn{2}{|l|}{ Length of follow-up (wks) } & \multirow{2}{*}{$\begin{array}{l}0 \\
34 \\
39\end{array}$} & \multirow{2}{*}{$\frac{<1}{68} \frac{1}{75}$} & \multirow{2}{*}{$\begin{array}{l}\frac{1-4}{67} \\
61\end{array}$} & \multirow{2}{*}{$\begin{array}{l}4-8 \\
50 \\
43\end{array}$} & \multirow{2}{*}{$\begin{array}{l}8-12 \\
38 \\
33\end{array}$} & \multirow{2}{*}{$\frac{>12}{26}$} & \multirow{2}{*}{$\begin{array}{l}\text { Total } \\
102 \\
114\end{array}$} \\
\hline No. followed & $\begin{array}{l}\text { Control } \\
\text { Trial }\end{array}$ & & & & & & & \\
\hline No. of recurrences & $\begin{array}{l}\text { Control } \\
\text { Trial }\end{array}$ & - & $\begin{array}{l}1 \\
1\end{array}$ & $\begin{array}{l}4 \\
7\end{array}$ & $\begin{array}{l}2 \\
3\end{array}$ & $\begin{array}{l}3 \\
0\end{array}$ & $\begin{array}{l}3 \\
6\end{array}$ & $\begin{array}{l}13 \\
17\end{array}$ \\
\hline $\begin{array}{l}\text { Cumulative recurrences as } \\
\text { percentage of cases followed }\end{array}$ & $\begin{array}{l}\text { Control } \\
\text { Trial }\end{array}$ & 二 & & $\begin{array}{r}7 \cdot 3 \\
10 \cdot 7\end{array}$ & & $\begin{array}{l}14 \cdot 6 \\
14 \cdot 7\end{array}$ & & $\begin{array}{l}19 \cdot 1 \\
22 \cdot 7\end{array}$ \\
\hline
\end{tabular}


starting treatment (see below) are also shown. Since most strains of Trichomonas are sensitive in vitro to levels of $0 \cdot 25-0 \cdot 125 \mu \mathrm{g} . / \mathrm{ml}$. (Jennison, Stenton, and Watt, 1961), it can be seen that values considerably above the minimum trichomonicidal level were maintained for at least 54 hours. Comparison with the fall-off of mean levels after single doses of $2 \mathrm{~g}$. metronidazole (Fig. 2) suggests that adequate levels might have persisted for another 24 hours; thus the 2-day course of treatment probably provides effective blood levels for 3 to 4 days.

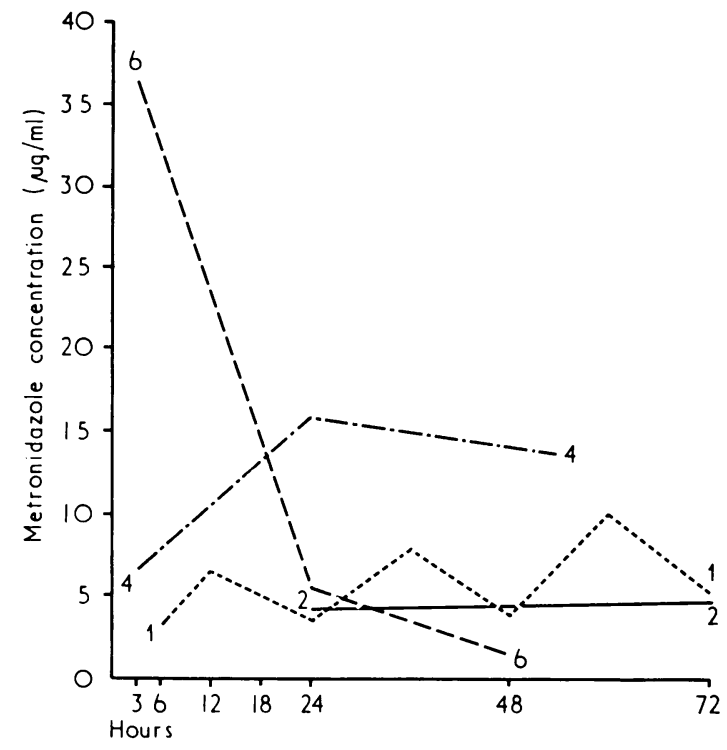

FIG. 2 Comparison of mean serum levels of metronidazole in subiects on four different dosage schedules;

$(6)=$ Six on 2 g. stat (IY'oodcock, 1972)

(4) $=$ Four on $400 \mathrm{mg}$. four times a day (Fig. 1)

(2) $=$ Two on $200 \mathrm{mg}$. three times a day (8 a.m. specimens) (Kane, McFadzean, Squires, King, and Nicol, 1961)

$(1)=$ One of the two above (12-hourly specimens)

\section{METRONIDAZOLE AND TETRACYCLINE}

Whilst the trial was being planned, Szanto (1971) suggested a possible antagonism between oxytetracycline and metronidazole. Four of the trial patients who were also taking tetracycline $500 \mathrm{mg}$. four times daily had blood specimens taken 36 hours after starting treatment. Their serum metronidazole levels are shown in Fig. 1, together with the results at 36 hours for four patients on metronidazole alone.
There was no significant difference in the values obtained.

A review of the case notes of 500 consecutive female patients previously treated with metronidazole for trichomoniasis revealed thirteen who had been taking tetracycline concurrently. Three did not return for follow-up; the remaining ten showed no failures. The original suggestion of antagonism was based on a single case of treatment failure and it seems likely that this was a chance occurrence.

\section{Discussion}

Since the introduction of metronidazole in 1959, the then recommended regimen has continued to prove so satisfactory in the treatment of trichomoniasis that there has been little impetus for its modification. However, the introduction of different dose schedules for other conditions such as gingivitis (Duckworth, Waterhouse, Britton, Nuki, Sheiham, Winter, and Blake, 1966) and amoebiasis (Powell, Macleod, Wilmot, and Elsdon-Dew, 1966; Powell, Wilmot, and Elsdon-Dew, 1967; Powell, 1969) has led to the recognition that there is nothing sacred about ' $200 \mathrm{mg}$. three times a day for 7 days'.

In the present trial the results obtained using a dosage of $400 \mathrm{mg}$. four times a day for 2 days were as good as those obtained by the traditional regime.

The relatively high cumulative recurrence rates of $22 \cdot 7$ and $19 \cdot 1$ per cent. should not be considered in absolute terms; the patients were followed for more than 3 months, allowing ample time for re-infection to have occurred, and no attempt was made to assess whether the consorts were treated adequately or to distinguish between treatment failure and re-infection.

\section{Summary}

114 women with vaginal trichomoniasis were treated with metronidazole $400 \mathrm{mg}$. four times a day for 2 days. A control group of 102 patients received metronidazole $200 \mathrm{mg}$. three times a day for 7 days.

Recurrence rates in those followed up during a period of 3 months or longer were seventeen of 75 (22.7 per cent.) and thirteen of $68(19 \cdot 1$ per cent.) respectively. No evidence was found of any antagonism between tetracycline and metronidazole.

I am grateful to Dr. F. J. G. Jefferiss and Dr. R. R. Willcox for allowing this trial to be undertaken on patients under their care. Thanks are also due to May and Baker Ltd. for providing the 'Flagyl' as $\mathbf{4 0 0} \mathrm{mg}$. tablets, and in particular to Mrs. O. Sheldon for her helpful advice and to Mr. S. Squires for estimating the serum levels of metronidazole. 


\section{References}

Csonka, G. W. (1971) Brit. F. vener. Dis., 47, 456

Duckworth, R., Waterhouse, J. P., Britton, D. E. R., Nuki, K., Sheiham, A., WINTER, R., and Blake, G. C. (1966) Brit. dent. F., 120, 599

Jennison, F. R., Stenton, P., and Watt, L. (1961) F. clin. Path., 14, 431

Kane, P. O., McFadzean, J. A., SQuires, S., King, A. J., and Nicol, C. S. (1961) Brit. F. vener. Dis., 37, 273

McClean, A. N. (1971) Ibid., 47, 36

Powell, S. J. (1969) Med. Today, 3, no. 1, p. 48

, MACLEOD, I., WILMOT, A. J., and ElSDON-DEW, R. (1966) Lancet, 2, 1329

-, Wilmot, A. J., and Elsdon-Dew, R. (1967) Ann. trop. Med. Parasitol., 61, 511
SzANTo, S. (1971) Brit. med. F., 2, 467

Woodcock, K. R. (1972) Brit. F. vener. Dis., 48, 65

Traitement de deux jours par le métronidazole dans la trichomonase vaginale SOMMAIRE

114 femmes atteintes de trichomonase vaginale furent traitées par une dose de $400 \mathrm{mg}$ de métronidazole donnée 4 fois par jour pendant 2 jours. Un groupe témoin de 102 malades reçut $200 \mathrm{mg}$ de métronidazole 3 fois par jour pendant 7 jours.

Les taux des rechutes chez les malades suivies pendant trois mois et plus furent respectivement de 17 sur 75 $(22,7$ pour cent) et de 13 sur 68 (19,1 pour cent). Aucun antagonisme entre tétracycline et métronidazole ne put être mis en évidence. 